\title{
Tuberculosis among HIV-infected population: incidence and risk factors in rural Tanzania
}

\author{
Said $\mathrm{K}^{1,2,3}$, Verver $\mathrm{S}^{4,5}$, Kalingonji $\mathrm{A}^{6}$, Lwilla $\mathrm{F}^{1}$, Mkopi A ${ }^{1}$, Charalambous $\mathrm{S}^{7}$, Reither $\mathrm{K}^{1,2,3}$
}

1. Ifakara Health Institute, Bagamoyo Research and Training Centre, P O Box 74, Tanzania

2. Swiss Tropical and Public Health Institute, Socinstrasse 57, 4002, Basel, Switzerland

3. University of Basel, Petersplatz 1, 4003 Basel, Switzerland

4. KNCV Tuberculosis Foundation, and Amsterdam Institute of Global Health and Development, Academic Medical Centre Amsterdam, The Netherlands

5. Department of Public Health, Erasmus MC, Rotterdam, The Netherlands

6. District AIDS Coordinator, CTC, Bagamoyo District Hospital, Bagamoyo, Tanzania

7. Aurum Institute, 29 Queens Road, Johannesburg, 2194, South Africa

\begin{abstract}
Background: The incidence of tuberculosis among HIV-infected populations with high CD4 count in high burden countries has not been well studied.

Objective: To assess the TB incidence in HIV-infected adults and its associated risk factors.

Method: A cohort study with retrospective review of medical records and prospective follow-up of HIV-infected adult participants attending CTC who were 18-55 years old, had CD4 count more than 250 cells $/ \mathrm{mm}^{3}$ in the period of 2008-2010 and were not on ART at enrolment. Cox proportional hazard regression was used to explore the predictors of incident TB.

Results: Overall 777 (24\%) of 3,279 CTC enrolled HIV-infected adults fulfilled the inclusion criteria of the study. The incidence of TB in the study population ranged from $0.8 / 100$ per person years (PY) at risk (95\% CI 0.5-1.3) in the main analysis to 1.7/100 $\mathrm{PY}$ at risk (95\% CI 1.0-2.6) in sensitivity analyses. Only prior history of TB disease was found to have a significant association with an increased risk of TB, hazard ratio 5.7 (95\% CI 2.0-16.4, p value 0.001$)$.

Conclusion: Tuberculosis incidence among HIV-infected adults with medium/high CD4 count in Bagamoyo is lower than in other high TB burden countries. Previously TB treated patients have a much higher risk of getting TB again than those who never had TB before.
\end{abstract}

Keywords: Tuberculosis, HIV, Care and Treatment Center, CD4 cell count

DOI: https://dx.doi.org/10.4314/ahs.v17i1.26

Cite as: Said K, Verver S, Kalingonji A, Lwilla F, Mkopi A, Charalambous S, Reither K. Tuberculosis among HIV-infected population: incidence and risk. factors in rural Tanzania. Afri Health Sci. 2017;17(1): https:/ / dx.doi.org/ 10.4314/ahs.v17i1.26

\section{Introduction}

Previous studies on HIV and Tuberculosis co-infection reported varying TB incidences among $\mathrm{HIV}$-infected population in high burden countries. A systematic review was done on TB incidence among HIV infected persons on $\mathrm{ART}^{1}$, but only very few studies have been done on TB
Corresponding author:
Said K,
Ifakara Health Institute,
Bagamoyo Research and Training
Centre,
P. O. Box 74, Tanzania
Tel: +255686997491
Email: ksaid@ihi.or.tz

incidence among ART naïve HIV-infected persons with medium/high CD4 count not on $\mathrm{ART}^{2-4}$. The lowest and highest incidences in these studies were 2.7 and 10.5 per 100 person years (PY), respectively, both reported from South Africa ${ }^{3,4}$. We chose to study this group since for a vaccine trial it was considered to include persons not on ART at the time of the study; and since HIV infected persons with medium/high CD4 count were often not on ART, although current recommendations are to give ART in persons living with HIV at any CD4 cell count ${ }^{5}$. In its End TB strategy, the World Health Organization (WHO) emphasizes treatment coverage to be $90 \%$ or more of total estimated TB cases annually ${ }^{6}$. This may be achieved when high-risk populations such as HIV-infected individuals are systematically screened and timely diagnosed. The study was designed to assess suitability of 
this population for vaccine trials and to determine TB screening strategies for HIV infected ART naïve persons. The specific objectives of this study were to measure the incidence of TB and its associated risk factors. This type of studies is rarely done and this information is useful to determine TB screening strategies for HIV-infected persons. We chose a rural area, since other studies have often been conducted in urban settings.

\section{Methods}

\section{Settings and participants}

The study was conducted in Bagamoyo District approximately 65 kilometers north of Dar es Salaam. The district has an estimated population of 311,740 (7). Data collection was done between June 2011 and June 2012. The two largest CTCs (Bagamoyo District Hospital and Chalinze Health Center) were selected for this study among seven CTCs which all offer HIV/TB collaboration activities. The study population comprised of patients enrolled to receive HIV care and treatment in two CTCs between 2008 and 2010.

\section{Study design}

We enrolled adults aged 18-55 years old from a cohort of HIV-infected individuals in the Bagamoyo District who had CD 4 count more than 250 cells $/ \mathrm{mm}^{3}$, had personal identifiers, locator information and were not on ART at enrolment to determine the incidence of TB and its predictors. Pre-ART registers of the National AIDS Control Program from 2008 to 2010 were reviewed to collect: unique CTC identification numbers, age and baseline CD4 cell count. Participants who were put on ART during CTC recruitment visit were excluded. Those who met the inclusion criteria were recruited and had their medical record reviewed to collect information on gender, TB status until 30 June 2012, baseline WHO clinical stage and ART status at follow-up. Recruited participants were interviewed using a structured questionnaire during their respective CTC follow-up visits or at home. A home visit to conduct interviews was done once. Participants that were not seen during their respective scheduled follow-up or home visits were considered lost to follow-up. For all TB cases, we reviewed TB Treatment and Laboratory registers to collect information on TB diagnosis date, smear results, type of $\mathrm{TB}$, treatment start and end dates. A participant was considered a TB case if: smear-posi- tive results were documented in the laboratory register and/or medical folder or the patient had smear-negative or missing smear results but had clinical signs and symptoms highly suggestive of TB, as determined by the treating clinician.

\section{Definitions}

Participants were classified into three categories according to the CD4+-T-cell counts at enrollment: high ( $>500$ cells $/ \mu \mathrm{l})$, medium (200 to 500 cells $/ \mu \mathrm{l})$ and low $(<200$ cells $/ \mu \mathrm{l})$.

Prevalent TB cases was defined as TB cases on treatment at enrolment or diagnosed within 3 months after enrolment.

Incident TB case was defined as TB case on treatment diagnosed more than 3 months after CTC enrolment.

\section{Statistical analysis}

Data was analyzed using STATA version 13 (College Station, Texas, USA). Differences in proportions were compared using $\chi^{2}$ test. A p-value of 0.05 was considered significant. Person-time at risk for TB was accrued from the date participant was enrolled into CTC until date of death, TB diagnosis or end of follow-up or end of observations on 30 June 2012, whichever occurred first (for the main analysis). TB cases on treatment at enrolment or diagnosed within 3 months after enrolment were considered prevalent cases.

Risk factors for incident TB were analysed by Cox proportional hazard ratio (HR). Risk factor analysis for TB included age, gender, WHO clinical stage, CD4 cell count at enrollment (250-350 and $>350$ cells $/ \mathrm{mm} 3)$, previous history of TB documented and ART start during follow-up were considered based on clinical relevance and availability.

\section{Main analysis:}

Date participant enrolled into CTC was considered as start date except for prevalent TB cases whose start date was a year after TB treatment completion. We assumed all participants were still living in the area, and all not registered in the TB register were assumed not to have TB until 30 June 2012.

In the sensitivity analysis we analyzed the effect of the assumption in the main analysis and varied assumptions on the point estimate and on the risk factors. 
Sensitivity analysis I: As in main analysis, but we excluded 35 participants who were not seen after enrollment visit ( 2 of these had TB at enrolment) since they may have moved outside the area, and their life status (alive or dead) and TB status (TB or no TB) was unknown to us. Sensitivity analysis II: as in Sensitivity Analysis I and we considered the end of follow-up to be date of TB diagnosis, last visit date (instead of 30 June 2012) or date of death whichever occurred first.

Sensitivity analysis III: As in sensitivity analysis II, but in addition we excluded 32 prevalent cases since those patients were probably identified with HIV due to TB symptoms, and therefore may not be representative for all HIV-infected persons with the selected CD4 cell count.

\section{Ethical consideration}

The study was approved by Ifakara Health Institute-Institutional Review Board (IHI/IRB/No.07-2011) and the Medical Research Coordinating Committee of National Institute of Medical Research (NIMR/HQ/R.8a/Vol. IX/1137).

Permission to review Pre-ART registers was obtained from the District Medical Office and District HIV Coordinator. All interviewed participants gave written informed consent before the interview.

\section{Results}

\section{General characteristics}

Among 3279 patients' pre ART records of CTC reviewed from 2008 to 2010, 777 (24\%) met the inclusion criteria and further review of their medical folders was done (Figure 1). Reasons for exclusion of 2,502 (76\%) patients shown in Figure 1.

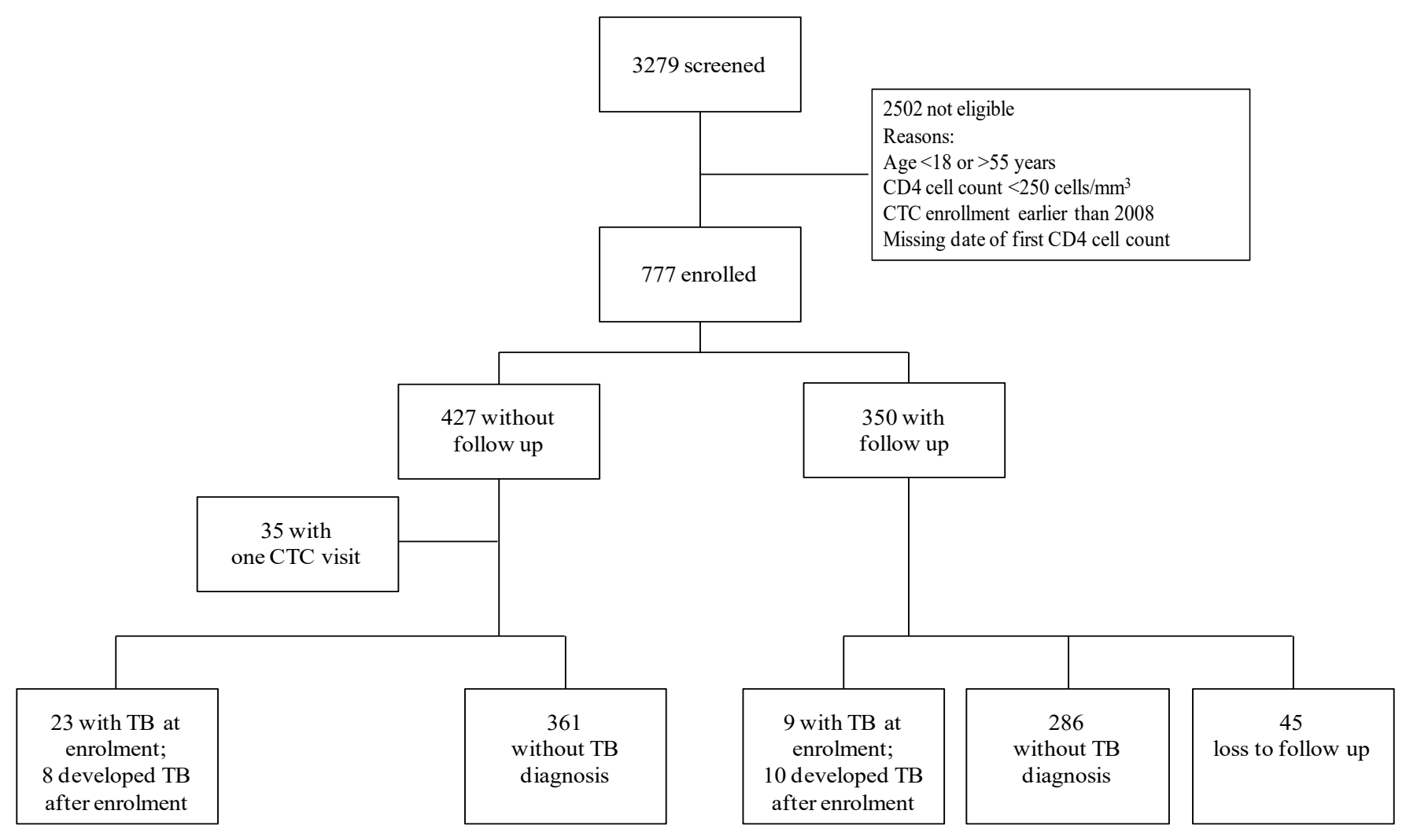

Figure 1: Flow chart showing CTC participants between 2008 and 2010 
Of the 777 participants, most were women 561/777 (72\%), 446/777 (57\%) aged between 18 and 35 years; median age was 34 years (interquartile range, [IQR] 29-41). The median baseline CD4 cell count was 458 cells $/ \mathrm{mm}^{3}$ (IQR 349-616): 580/777 (75\%) had CD4 cell count $>350$ cells $/ \mathrm{mm}^{3}$. A history of TB was registered in $49(6 \%)$ of the participants. The prevalence of TB at enrolment was 34/777 (4.4\%); 142 patients (18\%) were documented to have started ART during follow-up (Table 1). Among enrolled participants, those with follow-up visit (at home or in clinic) were comparable to those without follow-up visit, except that those with follow-up were more often females, had a lower WHO HIV clinical stage and more often started ART, although these differences were small (Table 1).

Table 1 Participants characteristic at baseline

\begin{tabular}{|c|c|c|c|c|c|c|}
\hline \multicolumn{2}{|l|}{ Characteristics } & \multirow{2}{*}{$\begin{array}{c}\text { Total participants } \\
\mathrm{N}=777, \mathrm{n}(\%)\end{array}$} & \multirow{2}{*}{$\begin{array}{l}\text { With follow-up * } \\
\qquad \mathrm{N}=350, \mathrm{n}(\%)\end{array}$} & \multirow{2}{*}{$\begin{array}{l}\text { Without follow-up* } \\
\qquad \mathrm{N}=427, \mathrm{n}(\%)\end{array}$} & \multirow[t]{2}{*}{$\chi^{2 *}$} & \multirow[t]{2}{*}{ Pvalue* } \\
\hline \multirow{3}{*}{ Sex } & & & & & & \\
\hline & Male & $216(28)$ & $79(23)$ & $137(32)$ & 8.7 & 0.003 \\
\hline & Female & $561(72)$ & $271(77)$ & $290(68)$ & & \\
\hline \multirow[t]{2}{*}{ Age (years) } & $18-35$ & $446(57)$ & $189(54)$ & $257(60)$ & 3.0 & 0.08 \\
\hline & $36-55$ & $331(43)$ & $161(46)$ & $170(40)$ & & \\
\hline \multirow[t]{5}{*}{ WHO stage } & 1 & $365(47)$ & $192(55)$ & $173(41)$ & 2.1 & 0.1 \\
\hline & 2 & $168(21)$ & $77(22)$ & $91(21)$ & & \\
\hline & 3 & $161(21)$ & $60(17)$ & $101(24)$ & 10.5 & 0.001 \\
\hline & 4 & $29(4)$ & $8(2)$ & $21(5)$ & 6.7 & 0.009 \\
\hline & Unclassified & $54(7)$ & $13(4)$ & $41(10)$ & 15.3 & $<0.001$ \\
\hline \multirow[t]{2}{*}{ Baseline CD4 } & $250-350$ & $197(25)$ & $91(26)$ & $106(25)$ & 0.1 & 0.7 \\
\hline & $>350$ & $580(75)$ & $259(74)$ & $321(75)$ & & \\
\hline \multirow[t]{3}{*}{ ART start during follow-up } & Yes & $142(18)$ & $83(24)$ & $59(14)$ & & \\
\hline & No & $504(65)$ & $246(70)$ & $258(60)$ & 4.1 & 0.04 \\
\hline & $\begin{array}{l}\text { Undocumen } \\
\text { ted }\end{array}$ & $131(17)$ & $21(6)$ & $110(26)$ & 52.0 & $<0.001$ \\
\hline \multirow[t]{3}{*}{ Previous TB history } & No episode & 720 (93) & 322 (97) & $401(94)$ & & \\
\hline & $\begin{array}{l}\text { At least } 1 \\
\text { episode }\end{array}$ & $49(6)$ & $9(2)$ & $19(4)$ & 1.7 & 0.2 \\
\hline & Unknown & $8(1)$ & $0(0)$ & $7(1.6)$ & 5.6 & 0.02 \\
\hline
\end{tabular}

\section{TB incidence rate}

\section{Main analysis}

In this analysis, 18 of 777 participants were incident TB cases; 7 were smear-positive, 3 were smear-negative and 8 TB cases smear results were not documented. Five participants were on ART at the time of TB diagnosis and 13 were started on ART after being diagnosed with TB.
The total survival time was 2197 PY. Overall TB incidence rate was 0.8 per $100 \mathrm{PY}$ at risk (95\% CI 0.5-1.3). Only one available risk factor, having at least one previous TB episode, was significantly associated with a higher TB incidence (rate 3.5; 95\% CI 1.4-8.4), (HR 5.7, 95\% CI 2.0-16.4, $\mathrm{p}=0.001)$ compared to those who report no previous TB episode (table 2 ). 
Table 2: Cox regression analysis of risk factor for $\mathrm{TB}$ incidence

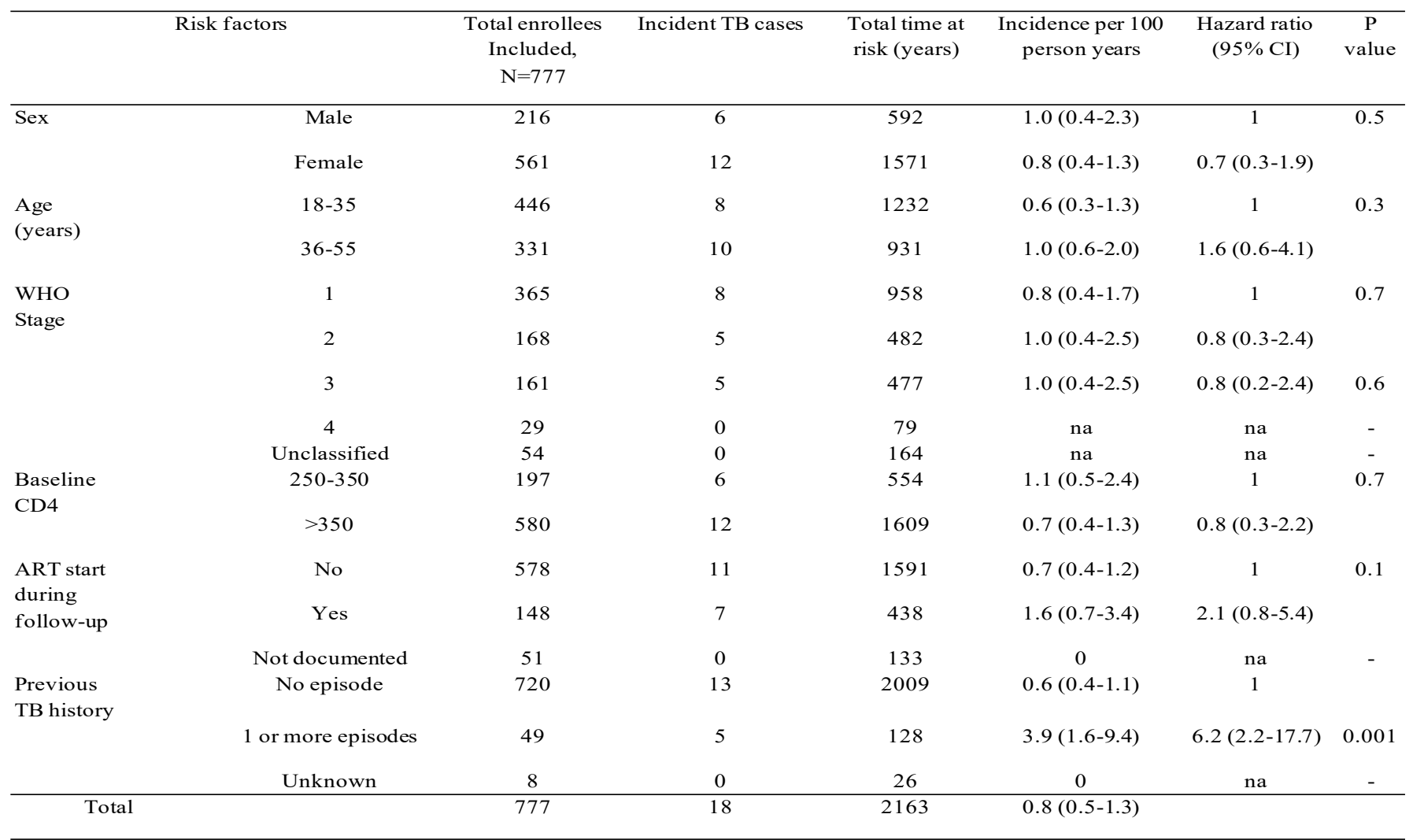

\section{CI: Confidence interval, Na: Not applicable}

Female gender, age less than 36 years, baseline CD4 cell count $>350$ cells $/ \mathrm{mm}^{3}$ and not being started on ART seemed to be associated with lower TB incidence rate, but were all not significant.

\section{Sensitivity analyses}

The TB incidences among HIV-infected population with CD 4 count higher than 250 cells $/ \mathrm{mm} 3$ were higher in all 3 sensitivity analyses compared to the main analysis (0.8 per 100 PY, 95\% CI 0.5-1.3), being 0.9/100 PY (95\% CI $0.5-1.4), 1.6 / 100$ PY (95\% CI 1.0-2.6), and 1.7/100 PY (95\% CI 1.0-2.6) in sensitivity analysis I, II and III, respectively (Table 3). A comparison of risk factors between different sensitivity analyses showed that hazard ratios were similar; the same risk factor (previous TB) remained significant and no new significant risk factors were found (table 3). 
Table 3: Cox regression analysis of the risk factor for TB incidence

\begin{tabular}{|c|c|c|c|c|c|c|c|c|c|c|c|c|c|c|c|c|}
\hline \multirow{2}{*}{\multicolumn{2}{|c|}{ Risk factors }} & \multirow{2}{*}{\multicolumn{5}{|c|}{ Sensitivity ana lysis I }} & \multirow{2}{*}{\multicolumn{5}{|c|}{ Sensitivity a na lysis II }} & \multirow{2}{*}{\multicolumn{5}{|c|}{ Sensitivity ana lysis III }} \\
\hline & & & & & & & & & & & & & & & & \\
\hline & & $\begin{array}{l}N= \\
735\end{array}$ & $\begin{array}{l}\text { Inci } \\
\text { dent } \\
\text { TB } \\
\text { case } \\
\text { s }\end{array}$ & $\begin{array}{l}\text { Time at } \\
\text { risk }\end{array}$ & $\begin{array}{l}\text { Incidenc } \\
\text { e per } \\
100 \\
\text { person } \\
\text { years }\end{array}$ & $\begin{array}{l}\text { HR } \\
(95 \% \\
\text { CI })\end{array}$ & $\begin{array}{l}N= \\
717\end{array}$ & $\begin{array}{l}\text { Inci } \\
\text { dent } \\
\text { TB } \\
\text { case } \\
\text { s } \\
\end{array}$ & $\begin{array}{l}\text { Time at } \\
\text { risk }\end{array}$ & $\begin{array}{l}\text { Incidence } \\
\text { per } 100 \\
\text { person } \\
\text { years }\end{array}$ & $\begin{array}{l}\text { HR } \\
(95 \% \mathrm{CI})\end{array}$ & $\begin{array}{l}\mathrm{N}= \\
703\end{array}$ & $\begin{array}{l}\text { Incide } \\
\text { nt TB } \\
\text { cases }\end{array}$ & $\begin{array}{l}\text { Time at } \\
\text { risk }\end{array}$ & $\begin{array}{l}\text { Incidence } \\
\text { per } 100 \\
\text { person } \\
\text { years }\end{array}$ & $\begin{array}{l}\text { HR } \\
(95 \% \mathrm{CI})\end{array}$ \\
\hline Total & & 735 & 18 & 2083 & $\begin{array}{c}0.9(0.5- \\
1.4)\end{array}$ & & 717 & 18 & 1105 & $\begin{array}{c}1.6(1.0- \\
2.6)\end{array}$ & & 703 & 18 & 1087 & $1.7(1.0-2.6)$ & \\
\hline \multirow[t]{2}{*}{ Sex } & M & 205 & 6 & 581 & $\begin{array}{c}1.0(0.5- \\
2.3)\end{array}$ & 1 & 195 & 6 & 280 & $\begin{array}{c}2.1(1.0- \\
4.8)\end{array}$ & 1 & 186 & 6 & 268 & $\begin{array}{c}2.2(1.0- \\
5.0)\end{array}$ & 1 \\
\hline & $\mathrm{F}$ & 530 & 12 & 1502 & $\begin{array}{c}0.8(0.5- \\
1.4)\end{array}$ & $\begin{array}{c}0.8(0.3- \\
2.0)\end{array}$ & 522 & 12 & 825 & $\begin{array}{c}1.4(0.8- \\
2.6)\end{array}$ & $\begin{array}{c}0.7(0.3- \\
1.8)\end{array}$ & 517 & 12 & 819 & $\begin{array}{c}1.4(0.8- \\
2.6)\end{array}$ & $0.7(0.3-1.8)$ \\
\hline \multirow[t]{2}{*}{$\begin{array}{l}\text { Age } \\
\text { (yrs) }\end{array}$} & $18-35$ & 414 & 8 & 1162 & $\begin{array}{c}0.7(0.3- \\
1.4)\end{array}$ & 1 & 404 & 8 & 600 & $\begin{array}{c}1.3(0.7- \\
2.7)\end{array}$ & 1 & 398 & 8 & 594 & $\begin{array}{c}1.3(0.7- \\
2.7)\end{array}$ & 1 \\
\hline & $36-55$ & 321 & 10 & 921 & $\begin{array}{c}1.1(0.6- \\
2.0)\end{array}$ & $\begin{array}{c}1.6(0.6- \\
4.0)\end{array}$ & 313 & 10 & 505 & $\begin{array}{c}2.0(1.1- \\
3.7)\end{array}$ & $\begin{array}{c}1.5(0.6- \\
3.7)\end{array}$ & 305 & 10 & 493 & $\begin{array}{c}2.0(1.1- \\
3.8)\end{array}$ & $1.5(0.6-3.7)$ \\
\hline \multirow[t]{5}{*}{$\begin{array}{l}\text { WHO } \\
\text { Stage }\end{array}$} & 1 & 347 & 8 & 545 & $\begin{array}{c}1.5(0.7- \\
2.9)\end{array}$ & 1 & 347 & 8 & 545 & $\begin{array}{c}1.5(0.7- \\
3.0)\end{array}$ & 1 & 345 & 8 & 543 & $\begin{array}{c}1.5(0.7- \\
3.0)\end{array}$ & 1 \\
\hline & 2 & 160 & 5 & 257 & $\begin{array}{c}1.9(0.8- \\
4.7)\end{array}$ & 1.3 & 160 & 5 & 257 & $\begin{array}{c}2.0(0.8- \\
4.7)\end{array}$ & 1.3 & 159 & 5 & 256 & $\begin{array}{c}2.0(0.8- \\
4.7)\end{array}$ & $0.9(0.3-2.9)$ \\
\hline & 3 & 144 & 5 & 226 & $\begin{array}{c}2.2(0.9- \\
5.3)\end{array}$ & 1.5 & 144 & 5 & 226 & $\begin{array}{c}2.2(1.0- \\
5.3)\end{array}$ & 1.5 & 133 & 5 & 211 & $\begin{array}{c}2.4(1.0- \\
5.7)\end{array}$ & $1.1(0.3-3.4)$ \\
\hline & 4 & 24 & 0 & 32 & $0(0-0)$ & na & 24 & 0 & 32 & $0(0-0)$ & na & 24 & 0 & 32 & $0(0-0)$ & na \\
\hline & \# & 42 & 0 & 45 & $0(0-0)$ & na & 42 & 0 & 45 & $0(0-0)$ & na & 42 & 0 & 45 & $0(0-0)$ & na \\
\hline $\begin{array}{l}\text { Baseli } \\
\text { ne }\end{array}$ & $\begin{array}{c}250- \\
350\end{array}$ & 189 & 6 & 538 & $\begin{array}{c}1.1(0.5- \\
2.5)\end{array}$ & 1 & 187 & 6 & 285 & $\begin{array}{c}2.1(1.0- \\
4.7)\end{array}$ & 1 & 182 & 6 & 275 & $\begin{array}{c}2.2(1.0- \\
4.9)\end{array}$ & 1 \\
\hline $\mathrm{CD} 4$ & $>350$ & 546 & 12 & 1545 & $\begin{array}{c}0.8(0.4- \\
1.4)\end{array}$ & $\begin{array}{c}0.8(0.3- \\
2.3)\end{array}$ & 530 & 12 & 820 & $\begin{array}{c}1.5(0.9- \\
2.6)\end{array}$ & $\begin{array}{c}0.8(0.3- \\
2.0)\end{array}$ & 521 & 12 & 812 & $\begin{array}{c}1.4(0.8- \\
2.6)\end{array}$ & $0.7(0.3-2.0)$ \\
\hline \multirow{3}{*}{$\begin{array}{l}\text { ART } \\
\text { at } \\
\text { follow } \\
\text {-up }\end{array}$} & No & 547 & 11 & 1534 & $\begin{array}{c}0.7(0.4- \\
1.3)\end{array}$ & 1 & 531 & 11 & 787 & $\begin{array}{c}1.3(0.8- \\
2.5)\end{array}$ & 1 & 524 & 11 & 781 & $\begin{array}{c}1.4(0.8- \\
2.5)\end{array}$ & 1 \\
\hline & Yes & 148 & 7 & 447 & $\begin{array}{c}1.6(0.7- \\
3.2)\end{array}$ & $\begin{array}{c}2.0(0.8- \\
5.2)\end{array}$ & 146 & 7 & 286 & $\begin{array}{c}2.5(1.2- \\
5.1)\end{array}$ & $\begin{array}{c}2.0(0.7- \\
5.1)\end{array}$ & 139 & 7 & 273 & $\begin{array}{c}2.5(1.2- \\
5.4)\end{array}$ & $2.0(0.8-5.2)$ \\
\hline & $\begin{array}{c}\text { Not } \\
\text { docum } \\
\text { ented }\end{array}$ & 40 & 0 & 102 & 0 & na & 40 & 0 & 32 & 0 & na & 40 & 0 & 34 & $0(0-0)$ & na \\
\hline \multirow{3}{*}{$\begin{array}{l}\text { Previo } \\
\text { us TB } \\
\text { episod } \\
\text { e }\end{array}$} & 0 & 682 & 13 & 1927 & $\begin{array}{c}0.7(0.4- \\
1.2)\end{array}$ & 1 & 674 & 13 & 1049 & $\begin{array}{c}1.2(0.7- \\
2.1)\end{array}$ & 1 & 666 & 13 & 1037 & $\begin{array}{c}1.3(0.7- \\
2.2)\end{array}$ & 1 \\
\hline & $\begin{array}{c}1 \text { or } \\
\text { more } \\
\text { TB } \\
\text { episod } \\
\text { e }\end{array}$ & 46 & 5 & 133 & $\begin{array}{c}4.0(1.6- \\
9.0)\end{array}$ & $\begin{array}{c}5.9(2.1- \\
17.0)\end{array}$ & 37 & 5 & 51 & $\begin{array}{c}10.0(4.0- \\
23)\end{array}$ & $\begin{array}{c}4.9(1.7- \\
14.5)\end{array}$ & 31 & 5 & 45 & $\begin{array}{c}11.1(4.6- \\
26.6)\end{array}$ & $5.2(1.7-15.4)$ \\
\hline & $\#$ & 7 & 0 & 23 & $0(0-0)$ & na & 6 & 0 & 5 & $0(0-0)$ & na & 6 & 0 & 5 & $0(0-0)$ & na \\
\hline
\end{tabular}

\section{Discussion}

The study assessed TB incidence rates and its associated risk factors for $\mathrm{HIV}$-infected adults with CD4 $>250 / \mathrm{mm}^{3}$ in rural Tanzania. The TB incidence was $0.8 / 100 \mathrm{PY}$ at risk; and was higher (between 0.9 and 1.7/100 PY at risk) with different sensitivity analyses. This tendency is due to fewer persons and less follow-up time being included compared to the main analysis. Those who did not participate in the follow-up are more likely to be alive and having no $\mathrm{TB}$, than being dead or having $\mathrm{TB}$, assuming that, if they suffered from TB or had HIV related co-morbidities they would have attended CTCs. Therefore we consider the main analysis the most accurate one, though TB incidence might be slightly underestimated.

The overall TB incidence among HIV-infected adults was low, this may be explained by high CD4 count. TB in HIV infection depends on the person's immune status (host), on the virulence of the virus (agent) and on external factors such as reinfections ${ }^{8,9}$. The incidence is lower than that reported in a systematic review summarizing findings from 32 cohorts of HIV-infected patients from high and intermediate tuberculosis burden settings taking $\mathrm{ART}^{1}$. A study in Ifakara, another rural area in Tanzania reported the TB incidence among HIV-infected persons to be $3.4 / 100 \mathrm{PY}^{2}$. In that study patients had no prior history of $\mathrm{TB}$, had more often stage 3 or 4 disease $(43 \%$ versus $24 \%$ in our study), and lower CD4 cell count. The TB incidence rate was also lower than that reported by a study in Dar es Salaam where the incidence among HIV-infected children $<15$ years was $5.2 / 100$ PY at risk ${ }^{10}$. However, our study population was adults and had higher CD4 cell counts relative to that in Dar es Salaam. Furthermore, our study setting was Pwani Region where TB notification rate was 187 per 100,000 population, lower than that of Dar es Salaam (428 per 100,000 population in year 2012) $)^{11}$

Our study found only one risk factor i.e. previous TB to be significantly associated with higher TB incidence. Other risk factors: gender, levels of CD4 cell count and 
ART start during follow-up were possibly not significant due to low numbers of patients included in analysis and therefore low power. The findings were consistent with those by Saha and Saha ${ }^{12}$ where the risk of TB among patients with past history of TB was 5 times higher than among those without previous TB. In the above study in Ifakara, WHO clinical stage 3 or 4 and being ART naïve were seen to be independent predictors of TB. In our study we found the same tendency but it was not significant ${ }^{2}$.

In this study TB incidence rate seemed to be higher among males than females. Our findings affirm the findings of the First National Tuberculosis Prevalence Survey in Tanzania where prevalence was higher in males than in females ${ }^{13}$. The findings are consistent with results from China ${ }^{14}$ and India ${ }^{15}$ as well as studies in Ethiopia and Brazil where males were reported to have an increased risk of TB even in HIV-infected population ${ }^{16,17}$. The lower incidence among females may be due to real lower incidence but also to concealment of a disease status by females because of fear of losing social status, marital problems, or harmful community reactions ${ }^{18}$.

Our study found that patients with active TB seemed to have lower CD 4 cell count than those without TB. Similar findings were reported from Iran and Ethiopia ${ }^{19,20}$.

Our study had a high proportion $(55 \%)$ of patients who had only one visit and could not be found anymore. Patients may choose to be followed-up in a district where they do not live due to fear of stigma. Another reason might be that persons never attend follow-up visits because of the perception that HIV infected individuals would be visibly sick and they are not ${ }^{21}$. Lastly patients may have died and this was not recorded in CTC records. Criteria for initiating ART in HIV-infected adults have changed since 2012. Tanzanian National AIDS Control Program recommends initiating ART in patients who (a) have current TB as AIDS defining illness or (b) CD4 below 500 cells $/ \mathrm{mm}^{3}$ or (c) WHO clinical stage 3 or 4 .

The strength of our study is that it was conducted using data that are routinely collected in Care and Treatment Centers and extra effort was done to trace those reported as loss to follow-up. Using regular surveillance data implied some missing data. The limitation of our study included: a slightly biased sample size towards participants with complete data, which is a lower risk group with respect to gender (females), WHO clinical stage (those with early stage disease i.e. stage $1 \& 2$ ), and those without prior
TB history who might be have had relapse of previous episode. Furthermore, numbers of TB cases are small that might be due to use of Ziehl Neelsen stain to diagnose $\mathrm{TB}$ at the time of the study, the incidence might have been higher if culture or advanced TB diagnostics such as Xpert MTB/RIF had been used ${ }^{22}$.

\section{Conclusion}

The TB incidence among HIV-infected adults in Bagamoyo is much higher than the country's estimated TB incidence of 327 per 100,000 population ${ }^{23}$. Those with previous TB have a higher risk to contract TB again and need special attention. Although this study may have limited power, in combination with similar studies in other sites, a meta-analysis can help to get enough power to find significant risk factors.

\section{Acknowledgements}

We acknowledge the great help received from Bagamoyo District Medical Officers, Ali Ali and Ummy Abdul from Ifakara Health Institute for their contributions in statistical analysis, Prof Gavin Churchyard for his guidance and support, the International Center for AIDS Care and Treatment Programs and the Bagamoyo Care and Treatment Centre staff. We also acknowledge the sponsor of the study (European and Developing Countries Clinical Trials Partnership; IP.2009.32080).

\section{Conflict of interest}

None to declare

\section{Author contributions}

Conceived and designed the study: KS, KR, SV, SC. Performed the study: KS, KR, FL, AK. Analyzed the data, KS, KR, SV, AM. Wrote the paper KS, SV, KR, AK, AM: All others approved the final version for publication.

\section{References}

1. Kufa T, Mabuto T, Muchiri E, Charalambous S, Rosillon D, Churchyard G, et al. Incidence of HIV-Associated Tuberculosis among Individuals Taking Combination Antiretroviral Therapy: A Systematic Review and Meta-Analysis. PloS One. 2014 Nov 13;9(11):e111209.

2. Haraka F, Glass TR, Sikalengo G, Gamell A, Ntamatungiro A, Hatz C, et al. A Bundle of Services Increased Ascertainment of Tuberculosis among HIV-Infected Individuals Enrolled in a HIV Cohort in Rural Sub-Saharan Africa. PloS One. 2015;10(4): e0123275. PubMed

3. Kufa T, Chihota V, Mngomezulu V, Charalambous S, 
Verver S, Churchyard G, et al. The incidence of tuberculosis among hiv-positive individuals with high CD4 counts: implications for policy. BMC Infect Dis. 2016;16(1):266 PubMed

4. Nicholas S, Sabapathy K, Ferreyra C, Varaine F, Pujades-Rodríguez M, AIDS Working Group of Médecins Sans Frontières. Incidence of tuberculosis in HIV-infected patients before and after starting combined antiretroviral therapy in 8 sub-Saharan African HIV programs. JAIDS. 2011 Aug 1;57(4):311-8.

5. WHO | Guideline on when to start antiretroviral therapy and on pre-exposure prophylaxis for HIV [Internet]. WHO. [cited 2016 Jun 20]. Available from: http://www. who.int/hiv/pub/guidelines/earlyrelease-arv/en/

6. WHO | WHO End TB Strategy [nternet]. WHO. [cited 2016 Jan 20]. Available from: http:/ /www.who.int/tb/ post2015_strategy/en/

7. The United Republic of Tanzania. Tanzania Population and Housing Census 2012.

8. Sgaragli G, Frosini M. Human Tuberculosis I. Epidemiology, Diagnosis and Pathogenetic Mechanisms. Curr Med Chem. 2016;23(25):2836-73. PubMed

9. Smith I. Mycobacterium tuberculosis pathogenesis and molecular determinants of virulence. Clin Microbiol Rev. 2003 Jul;16(3):463-96.

10. Li N, Manji KP, Spiegelman D, Muya A, Mwiru RS, Liu E, et al. Incident tuberculosis and risk factors among HIV-infected children in Tanzania. AIDS Lond Engl. 2013 May 15;27(8):1273-81.

11. Ministry of Health and Social Welfare, National Tuberculosis and Leprosy Programme, United Republic of Tanzania. Manual for the Management of Tuberculosis and Leprosy. Sixth Edition. Ministry of Health and Social Welfare; 2013.

12. Saha R, Saha I. Risk of Tuberculosis Among HAART Receiving HIV Patients Attending an ART Centre of West Bengal, India: A Prospective Cohort Study. J Community Health. 2014 Oct;39(5):935-42.

13. Senkoro M, Hinderaker SG, Mfinanga SG, Range N, Kamara DV, Egwaga S, et al. Health care-seeking behaviour among people with cough in Tanzania: findings from a tuberculosis prevalence survey. Int J Tuberc Lung Dis Off J Int Union Tuberc Lung Dis. 2015 Jun;19(6):640-6. 14. Chen W, Shu W, Wang M, Hou Y, Xia Y, Xu W, et al.
Pulmonary Tuberculosis Incidence and Risk Factors in Rural Areas of China: A Cohort Study. PLoS ONE. 2013 Mar 12;8(3):e58171.

15. Kamath R, Sharma V, Pattanshetty S, Hegde MB, Chandrasekaran V. HIV-TB coinfection: Clinico-epidemiological determinants at an antiretroviral therapy center in Southern India. Lung India Off Organ Indian Chest Soc. 2013;30(4):302-6.

16. Taha M, Deribew A, Tessema F, Assegid S, Duchateau L, Colebunders R. Risk Factors of Active Tuberculosis in People Living with HIV/AIDS in Southwest Ethiopia: A Case Control Study. Ethiop J Health Sci. 2011 Jul;21(2):131-9.

17. do Prado TN, Miranda AE, de Souza FM, Dias E dos S, Sousa LKF, Arakaki-Sanchez D, et al. Factors associated with tuberculosis by HIV status in the Brazilian national surveillance system: a cross sectional study. BMC Infect Dis. 2014;14:415.

18. Atre S, Kudale A, Morankar S, Gosoniu D, Weiss MG. Gender and community views of stigma and tuberculosis in rural Maharashtra, India. Glob Public Health. 2011;6(1):56-71. PubMed

19. Tabarsi P, Mirsaeidi SM, Amiri M, Mansouri SD, Masjedi MR, Velayati AA. Clinical and laboratory profile of patients with tuberculosis/HIV coinfection at a national referral centre: a case series. East Mediterr Health J Rev Santé Méditerranée Orient Al-Majallah Al-sihhiīyah LiSharq Al-Mutawassit. 2008 Apr;14(2):283-91.

20. Teck R, Ascurra O, Gomani P, Manzi M, Pasulani O, Kusamale J, et al. WHO clinical staging of HIV infection and disease, tuberculosis and eligibility for antiretroviral treatment: relationship to CD4 lymphocyte counts. Int J Tuberc Lung Dis Off J Int Union Tuberc Lung Dis. 2005 Mar;9(3):258-62.

21. Layer EH, Kennedy CE, Beckham SW, Mbwambo JK, Likindikoki S, Davis WW, et al. Multi-Level Factors Affecting Entry into and Engagement in the HIV Continuum of Care in Iringa, Tanzania. PloS One. 2014;9(8):e104961. 22. Bajrami R, Mulliqi G, Kurti A, Lila G, Raka L. Comparison of GeneXpert MTB/RIF and conventional methods for the diagnosis of tuberculosis in Kosovo. $J$ Infect Dev Ctries. 2016 Apr 28;10(4):418-22.

23. WHO | Global tuberculosis report 2014 [Internet]. WHO. [cited 2014 Oct 22]. Available from: http:/ /www. who.int/tb/publications/global_report/en/ 